\title{
Chromium (III) Oxide Carbon Nanocomposites Lithium-ion Battery Anodes with Enhanced Energy Conversion Performance
}

Ya Fu, ${ }^{1}$ Hongbo Gu, ${ }^{3}$ Xingru Yan, ${ }^{2}$ Jiurong Liu ${ }^{1} *$, Yiran Wang, ${ }^{2}$ Jiangnan Huang, ${ }^{2}$ Xiaoyu Li, ${ }^{1}$ Hailong Lv, ${ }^{1}$ Xinzhen Wang, ${ }^{1}$ Jiang Guo, ${ }^{2}$ Guixia Lu, ${ }^{1}$ Song Qiu ${ }^{1}$, Zhanhu Guo ${ }^{2 *}$

${ }^{1}$ Key Laboratory for Liquid-Solid Structural Evolution and Processing of Materials, Ministry of Education and School of Materials Science and Engineering, Shandong University, Jinan, Shandong 250061, China

${ }^{2}$ Integrated Composites Laboratory (ICL), Department of Chemical and Biomolecular Engineering, University of Tennessee, Knoxville, TN 37996 USA

${ }^{3}$ Department of Chemistry, Tongji University, Shanghai, 200092, People's Republic of China

*Corresponding authors.

E-mail addresses: jrliu@sdu.edu.cn (J. L.); zguo10@utk.edu (Z.G.) 


\begin{abstract}
The chromium (III) oxide $\left(\mathrm{Cr}_{2} \mathrm{O}_{3}\right)$ nanoparticles embedded in the carbon sheets are fabricated by combining a sol-gel approach with an efficient carbonization process using glycine as carbon precursor. These $\mathrm{Cr}_{2} \mathrm{O}_{3}$ /carbon nanocomposites serving as anode materials for lithium-ion batteries (LIBs) have been tested, exhibiting higher cycling (reversible capacity of $465.5 \mathrm{mAh} \mathrm{g}^{-1}$ after 150 cycles at a current density of $100 \mathrm{~mA} \mathrm{~g}^{-1}$ ) and rate performances (the discharge capacities of $448.7,287.2$, and $144.8 \mathrm{mAh} \mathrm{g}^{-1}$ at a current density of 200,400 , and $800 \mathrm{~mA} \mathrm{~g}^{-1}$, respectively) than pure $\mathrm{Cr}_{2} \mathrm{O}_{3}$ (reversible capacity of $71.2 \mathrm{mAh} \mathrm{g}^{-1}$ after 150 cycles at a current density of $100 \mathrm{~mA} \mathrm{~g}^{-1}$ and the discharge capacities of $174.4,60.5,29.5$, and $13.6 \mathrm{mAh} \mathrm{g}^{-1}$ at a current density of $100,200,400$, and $800 \mathrm{~mA} \mathrm{~g}^{-1}$, respectively) due to the presence of carbon sheets, which efficiently buffer the volume change during the lithiation/delithiation and improve the electrical conductivity between $\mathrm{Cr}_{2} \mathrm{O}_{3}$ nanoparticles.
\end{abstract}

Keywords: chromium (III) oxide; anode materials; carbon; lithium-ion battery. 


\section{Introduction}

Lithium-ion batteries (LIBs) have become sustainable and renewable power sources for various portable electronic devices due to their high voltage, high energy density and long lifespan [1-3]. Transition-metal oxides, such as cobalt (II,III) oxide $\left(\mathrm{Co}_{3} \mathrm{O}_{4}\right)$ [4, 5], manganese (II) oxide $(\mathrm{MnO})$ [6], magnetite $\left(\mathrm{Fe}_{3} \mathrm{O}_{4}\right)$ [7], copper $(\mathrm{II})$ oxide $(\mathrm{CuO})$ [8], etc., have been considered as potential anode materials for LIBs because they possess a theoretical specific capacity far larger than the commercial graphite material (372 $\mathrm{mAh} \mathrm{g}^{-1}$ ) [9]. For example, chromium (III) oxide $\left(\mathrm{Cr}_{2} \mathrm{O}_{3}\right)$ has also been reported as anode materials for LIBs with a theoretical capacity of $1058 \mathrm{mAh} \mathrm{g}^{-1}$ and relatively low electromotive force (EMF) value of $1.085 \mathrm{~V}$ [10]. $\mathrm{Cr}_{2} \mathrm{O}_{3}$ follows a similar mechanism to that of other transition metal oxides, i.e., $6 \mathrm{Li}^{+}+\mathrm{Cr}_{2} \mathrm{O}_{3}+6 \mathrm{e}^{-} \rightleftharpoons 3 \mathrm{Li}_{2} \mathrm{O}+2 \mathrm{Cr}$. However, similar to other pure metal oxide anodes, $\mathrm{Cr}_{2} \mathrm{O}_{3}$ still has challenges or disadvantages including fast capacity fading and low rate performance due to its drastic volume expansion/contraction, and severe structural destruction during discharge/charge processes [11].

Various strategies have been used to improve the cycling and rate performance of $\mathrm{Cr}_{2} \mathrm{O}_{3}$, such as downsizing particles [12], constructing porous nanostructures [13], and preparing composites [14, 15]. Among these methods, carbon composites have been widely investigated since carbon can not only cushion the stress from volume expansion of active materials and maintain the structural integrity of electrode during cycling, but also prevent the agglomeration of metal oxide particles. Therefore, the addition of carbon has brought an evident effect on the improvement of cycling stability $[16,17]$. For example, carbon-coated graphene- $\mathrm{Cr}_{2} \mathrm{O}_{3}$ 
composites, which were synthesized using a hydrothermal method followed by a subsequent thermal treatment, exhibit a reversible capacity of more than $550 \mathrm{mAh} \mathrm{g}^{-1}$ after 100 cycles [14]. The carbon coating formed simultaneously with $\mathrm{Cr}_{2} \mathrm{O}_{3}$ particles could separate the particles and limit their growth, which resulted in the enhancement of electrochemical performances [14]. However, this approach suffers from high cost and complicated operation, which limit its practical application. Jiang et al [18]. reported that the $\mathrm{Cr}_{2} \mathrm{O}_{3}-\mathrm{C}$ hierarchical core/shell nanospheres exhibit better cycling performance (600 $\mathrm{mAh} \mathrm{g}^{-1}$ after 35 cycles) than pure mesoporous $\mathrm{Cr}_{2} \mathrm{O}_{3}$ spheres (320 mAh g-1 after 35 cycles), while the $\mathrm{Cr}_{2} \mathrm{O}_{3}-\mathrm{C}$ hierarchical core/shell nanospheres still showed poor cycling stability and the capacity decreased successively with cycling.

In this work, a facile approach to prepare the $\mathrm{Cr}_{2} \mathrm{O}_{3} /$ carbon nanocomposites by directly carbonizing glycine- $\mathrm{CrCl}_{3}$ gel precursor is reported for the first time. The crystalline structure of the $\mathrm{Cr}_{2} \mathrm{O}_{3}$ /carbon and pure $\mathrm{Cr}_{2} \mathrm{O}_{3}$ samples is investigated by XRD. TGA and DSC tests have been carried out to evaluate the carbon content in the synthesized $\mathrm{Cr}_{2} \mathrm{O}_{3} /$ carbon sample. Scanning electron microscope (SEM) and transmission electron microscopy (TEM) are used to characterize the structures and morphologies of the prepared $\mathrm{Cr}_{2} \mathrm{O}_{3} /$ carbon nanocomposites. The electrochemical performances of prepared $\mathrm{Cr}_{2} \mathrm{O}_{3} /$ carbon nanocomposites as anode materials for LIBs are evaluated by cyclic voltammogram (CV), galvanostatic charge-discharge and electrochemical impedance spectroscopy (EIS) measurement techniques.

\section{Experimental}




\subsection{Materials}

Chromic chloride $\left(\mathrm{CrCl}_{3} \cdot 6 \mathrm{H}_{2} \mathrm{O}\right)$, glycine $\left(\mathrm{NH}_{2} \mathrm{CH}_{2} \mathrm{COOH}\right)$, ammonium hydroxide $\left(\mathrm{NH}_{3} \cdot \mathrm{H}_{2} \mathrm{O}\right.$ ), polyvinylidene fluoride (PVDF) and N-Methyl-2-pyrrolidone (NMP) were purchased from Sinopharm Chemical Reagent Co., Ltd. Carbon black, Li foil and Celgard 2300 were purchased from Hefei Kejing Material Technology Co., Ltd, China. LiPF (dissolved in ethylene carbonate, dimethyl carbonate, and ethylene methyl carbonate with a volume ratio of 1 :

1: 1) was purchased from Shenzhen Biyuan Technology Co., Ltd, China. All the chemicals were analytical grade and used as received without any further purification.

\subsection{Preparation of $\mathrm{Cr}_{2} \mathrm{O}_{3} /$ carbon nanocomposites and pure $\mathrm{Cr}_{2} \mathrm{O}_{3}$ nanoparticles}

The $\mathrm{Cr}_{2} \mathrm{O}_{3}$ nanoparticles embedded in the carbon sheets were fabricated by combining a sol-gel approach with an efficient carbonization process using glycine as carbon precursor. Briefly, $0.1 \mathrm{~mol} \mathrm{CrCl}_{3} \cdot 6 \mathrm{H}_{2} \mathrm{O}$ and $0.08 \mathrm{~mol}$ glycine were dissolved in $30 \mathrm{~mL}$ deionized water under magnetic stirring, and then the solution was transferred into a vessel. The gel precursor was obtained after the solution was aged and dried in air for two weeks. Then the gel precursor was carbonized at $550{ }^{\circ} \mathrm{C}$ for $5 \mathrm{~h}$ in a tube furnace under nitrogen flux to prepare $\mathrm{Cr}_{2} \mathrm{O}_{3} /$ carbon nanocomposites. The preparation procedure of the $\mathrm{Cr}_{2} \mathrm{O}_{3} /$ carbon nanocomposites is shown in Scheme 1. Pure carbon (C) was prepared in the same way except the addition of $\mathrm{CrCl}_{3} \cdot 6 \mathrm{H}_{2} \mathrm{O}$. Pure $\mathrm{Cr}_{2} \mathrm{O}_{3}$ nanoparticles were also prepared for comparison. Briefly, $0.1 \mathrm{~mol} \mathrm{CrCl}_{3} \cdot 6 \mathrm{H}_{2} \mathrm{O}$ was dissolved in $30 \mathrm{~mL}$ deionized water. Then $13 \mathrm{~mL}$ ammonium hydroxide ( $25 \mathrm{wt} \%)$ was added into the above solution dropwise under magnetic stirring for $30 \mathrm{~min}$. The $\mathrm{Cr}(\mathrm{OH})_{3}$ precipitate was centrifuged, washed using deionized water for several times, and dried at $50{ }^{\circ} \mathrm{C}$ in an oven 
overnight. $\mathrm{Cr}_{2} \mathrm{O}_{3}$ was obtained by sintering $\mathrm{Cr}(\mathrm{OH})_{3}$ at $550{ }^{\circ} \mathrm{C}$ for $5 \mathrm{~h}$ in a furnace.

\subsection{Characterizations}

X-ray diffraction (XRD) analysis was carried out on a Rigaku D/Max-RC X-ray diffractometer with $\mathrm{Ni}$ filtered $\mathrm{Cu} K \alpha$ radiation $(\lambda=0.1542 \mathrm{~nm}, V=40 \mathrm{kV}, I=40 \mathrm{~mA})$ in the range of $10 \sim 80^{\circ}$ at a scanning rate of $4^{\circ} \mathrm{min}^{-1}$. Thermogravimetric analysis (TGA) and differential scanning calorimetry (DSC) were performed from ambient temperature to $800{ }^{\circ} \mathrm{C}$ in air at a heating rate of $10{ }^{\circ} \mathrm{C} \min ^{-1}$ using a SDT thermal-microbalance apparatus. Raman spectra were obtained by a Renishaw confocal Raman microspectroscopy (Renishaw Co. Ltd., Gloucestershire, U.K.) with a laser excitation wave length of $780 \mathrm{~nm}$.Fourier transform infrared spectroscopy (FTIR) was recorded on a VERTEX-70FT-IR spectrometer. X-ray photoelectron spectroscopy (XPS) was conducted on a Kratos Analytical spectrometer, using Al $K \alpha=1486.6$ $\mathrm{eV}$ radiation as the excitation source, under a condition of anode voltage of $12 \mathrm{kV}$ and an emission current of $10 \mathrm{~mA}$. The microstructure of the sample was observed on a JSM-6700F field emission scanning electron microscope (SEM), and a JEOL JEM-2100 transmission electron microscopy (TEM). The $\mathrm{N}_{2}$ adsorption-desorption isotherms of hollow porous cobalt structures were measured at $77 \mathrm{~K}$ on a Quadrasorb-SI instrument. The specific surface area (SBET) was calculated with the Brunauer-Emmett-Teller (BET) model and the pore size distribution was calculated by the density functional theory (DFT) method.

The working electrode was prepared as follows. The active anode composite material, carbon black, and PVDF with a weight ratio of 8: 1: 1 were mixed in NMP to form a homogenous slurry. The slurry was coated on a copper foil substrate and dried in a vacuum oven 
at $120{ }^{\circ} \mathrm{C}$ for $12 \mathrm{~h}$. The CR2025-type cells were assembled using Li foil as counter electrode, Celgard 2300 as separator, and 1.0 M LiPF6 as electrolyte in a glovebox filled with argon atmosphere. The charge-discharge experiments were performed on a LAND CT2001A battery test system over a voltage of $0.02 \sim 3 \mathrm{~V}$ at various current densities. The cyclic voltammetry $(\mathrm{CV})$ experiment was performed on a IviumStat electrochemistry workstation with a scanning rate of $0.1 \mathrm{mV} \mathrm{s}^{-1}$ and the potential $v s . \mathrm{Li} / \mathrm{Li}^{+}$ranging from 0.01 to $3 \mathrm{~V}$. The electrochemical impedance spectroscopy (EIS) was tested on the same instrument with AC signal amplitude of $10 \mathrm{mV}$ in the frequency range from $100 \mathrm{kHz}$ to $0.01 \mathrm{~Hz}$.

\section{Results and discussion}

Fig. 1A shows the XRD patterns of the as-prepared nanocomposites and pure $\mathrm{Cr}_{2} \mathrm{O}_{3}$ nanoparticles. All the peaks can be indexed as $\mathrm{Cr}_{2} \mathrm{O}_{3}$ with the lattice parameters of $a=4.959, b=$ 4.959 and $c=13.594 \mathrm{~nm}$ (JCPDS No.38-1479). There is no peak of any other phases, indicating that $\mathrm{Cr}_{2} \mathrm{O}_{3}$ has been obtained for the $\mathrm{Cr}_{2} \mathrm{O}_{3}$ /carbon nanocomposites after high-temperature treatment in the presence of carbon. According to the Scherrer's formula [19, 20]: $\beta=k \lambda / L \cos \theta$, where $\lambda$ is the $\mathrm{X}$-ray wavelength $(\lambda=0.154 \mathrm{~nm}), L$ is the average crystallite size, $k$ is the shape factor and $k=0.89, \beta$ is the full width at half maximum, and $\theta$ is Bragg angle in degree, the average crystalline size of $\mathrm{Cr}_{2} \mathrm{O}_{3}$ for the $\mathrm{Cr}_{2} \mathrm{O}_{3}$ /carbon sample composites is calculated to be about $30 \mathrm{~nm}$, based on the $\left(\begin{array}{lll}1 & 0 & 4\end{array}\right)$ peak at $2 \theta=33.4^{\circ}$.

Fig. 1B shows the FT-IR spectra of the gel precursor consisted $\mathrm{CrCl}_{3}$ with glycine and $\mathrm{Cr}_{2} \mathrm{O}_{3}$ /carbon nanocomposites. In the FT-IR spectrum of the gel precursor, Fig. 1B-a, two peaks 
are observed between 2500 and $3600 \mathrm{~cm}^{-1}$. The peak at $3123 \mathrm{~cm}^{-1}$ is attributed to the $\mathrm{C}-\mathrm{H}$ bonds of glycine, and the shoulder peak at $3386 \mathrm{~cm}^{-1}$ is assigned to the $\mathrm{O}-\mathrm{H}$ stretching vibration arising from water molecules remained in the gel precursor and the hydroxyl groups of glycine [21]. The peaks at 1665,1469 and $1345 \mathrm{~cm}^{-1}$ are related to the stretching vibration of C-O, N-H and C-C bonds, respectively. These vibration modes are known to be the signatures of amino acids [22, 23]. For the $\mathrm{Cr}_{2} \mathrm{O}_{3} /$ carbon nanocomposites, the absorption peaks at 3426,1395 and $1621 \mathrm{~cm}^{-1}$ (Fig. 1B-b) are assigned to the stretching vibrations of O-H, C-C and C-O groups [24], respectively, while the peaks of $\mathrm{C}-\mathrm{H}\left(3123 \mathrm{~cm}^{-1}\right)$ and $\mathrm{N}-\mathrm{H}\left(1469 \mathrm{~cm}^{-1}\right)$ (Fig. 1B-a) are disappeared after carbonization. The bands at 570 and $625 \mathrm{~cm}^{-1}$ are associated with the vibration mode of O-Cr-O bonds, confirming the formation of $\mathrm{Cr}_{2} \mathrm{O}_{3}$ phase [25]. The FT-IR results indicate that glycine in gel precursor has been transformed into carbon structure and $\mathrm{Cr}_{2} \mathrm{O}_{3}$ has been generated during the carbonization process, which is consistent with the XRD analysis.

TGA and DSC tests have been carried out to evaluate the carbon content in the synthesized $\mathrm{Cr}_{2} \mathrm{O}_{3}$ /carbon sample. The results are shown in Fig. 1C. The weight losses can be distinguished into two stages in the TGA profiles. In the first stage from room temperature to $200{ }^{\circ} \mathrm{C}$, the weight loss of about $3.0 \%$ is due to the evaporation of water absorbed on the surface of $\mathrm{Cr}_{2} \mathrm{O}_{3}$ /carbon sample. The second stage around $200 \sim 400{ }^{\circ} \mathrm{C}$ with about $14.2 \%$ weight loss, corresponding to the exothermic peak in the DSC curve, is attributed to the oxidation process of carbon to form volatile species such as $\mathrm{CO}$ and $\mathrm{CO}_{2}$. After $400{ }^{\circ} \mathrm{C}$, there are no apparent exothermal peak and weight loss observed, suggesting the complete oxidation of carbon. Thus, $\mathrm{Cr}_{2} \mathrm{O}_{3}$ accounts for $82.8 \%$ of the total weight in the formed carbon nanocomposites. The Raman 
spectra of $\mathrm{Cr}_{2} \mathrm{O}_{3}$ /carbon nanocomposites are shown in Fig. 1D. The broad peaks located at about 1356 and $1596 \mathrm{~cm}^{-1}$ are assigned to the D band (disordered carbon) and $\mathrm{G}$ band (graphitic carbon) of carbon materials, respectively $[26,27]$. The intensity ratio of the two peaks $\left(\mathrm{I}_{\mathrm{D}} / \mathrm{I}_{\mathrm{G}}\right)$ could be used to evaluate the disordered degree of carbon materials. The ratio of ca. 1.0 indicates the low graphitization degree of carbon sheets, which is consistent with the result of XRD.

The chemical composition of the $\mathrm{Cr}_{2} \mathrm{O}_{3}$ /carbon nanocomposites is investigated by XPS and the results are shown in Fig. 2. In the survey scan XPS spectrum of the $\mathrm{Cr}_{2} \mathrm{O}_{3} /$ carbon nanocomposites, Fig. 2a, the peaks of $\mathrm{Cr} 2 \mathrm{p}, \mathrm{O} 1 \mathrm{~s}, \mathrm{C} 1 \mathrm{~s}$ and $\mathrm{N} 1 \mathrm{~s}$ are observed, indicating the existence of $\mathrm{Cr}, \mathrm{O}, \mathrm{C}$ and $\mathrm{N}$ elements in the prepared $\mathrm{Cr}_{2} \mathrm{O}_{3} /$ carbon nanocomposites. The deconvoluted C 1s peaks at 284.7 and $286.2 \mathrm{eV}$ (Fig. 2b) correspond to the $\mathrm{C}-\mathrm{C}$ and $\mathrm{C}-\mathrm{O}$ components, respectively [24]. The deconvoluted peaks around 398 and $400 \mathrm{eV}$ (Fig. 2c) in the $\mathrm{N}$ 1s XPS spectrum demonstrate the formation of $-\mathrm{N}=(398.0 \mathrm{eV})$ and $-\mathrm{NH}-(400.2 \mathrm{eV})$ in the carbon sheets [28]. Our previous work has confirmed that the N-doped carbon nanocomposites were favorable to the enhancement of electrochemical performances [29]. As shown in Fig. 2d, the peaks at 576.9 and $586.4 \mathrm{eV}$ are assigned to $\mathrm{Cr} 2 \mathrm{p}_{3 / 2}$ and $\mathrm{Cr} 2 \mathrm{p}_{1 / 2}$, respectively [30, 31].

Fig. 3a\&b show the SEM images of pure $\mathrm{Cr}_{2} \mathrm{O}_{3}$ and $\mathrm{Cr}_{2} \mathrm{O}_{3}$ /carbon nanocomposites, respectively. The observed sheets in Fig. $3 b$ are carbon according to the TGA test. In Fig. 3b, it's clear that the synthesized $\mathrm{Cr}_{2} \mathrm{O}_{3}$ /carbon nanocomposites are composed of $\mathrm{Cr}_{2} \mathrm{O}_{3}$ particles and carbon sheets. A close inspection from TEM image (Fig. 3c) reveals that $\mathrm{Cr}_{2} \mathrm{O}_{3}$ nanoparticles are embedded in the carbon sheet matrix. As shown in Fig. $3 \mathrm{c}$, the $\mathrm{Cr}_{2} \mathrm{O}_{3}$ nanoparticles have a size 
distribution ranging from 20 to $40 \mathrm{~nm}$. In the high resolution TEM (HR-TEM) image (Fig. 3d), the typical lattice fringe spacing is measured to be $0.227 \mathrm{~nm}$, corresponding to the $\left(\begin{array}{ll}0 & 0\end{array}\right)$ crystal plane of rhombohedral eskolaite $\mathrm{Cr}_{2} \mathrm{O}_{3}$, which is consisted with the XRD result. The elemental mapping of the selected area obtained on SEM is displayed in Fig. 3e, f\&g, clearly demonstrating a uniform distribution of $\mathrm{Cr}$, $\mathrm{O}$ and $\mathrm{C}$ elements. The nitrogen absorption-desorption isotherms and the corresponding pore size distribution of $\mathrm{Cr}_{2} \mathrm{O}_{3} /$ carbon nanocomposites are shown in Fig. 4. The isotherms can be ascribed to type IV with a hysteresis loop, indicating the presence of mesopores [32]. From the pore size distribution curve (inset in Fig. 4), the pore size is observed nonuniform ranging from several to $70 \mathrm{~nm}$. The BET specific surface area and the pore volume of $\mathrm{Cr}_{2} \mathrm{O}_{3} /$ carbon nanocomposites were $39.5 \mathrm{~m}^{2} \mathrm{~g}^{-1}$ and 0.049 $\mathrm{cm}^{3} \mathrm{~g}^{-1}$, respectively.

The discharge/charge curves of $\mathrm{Cr}_{2} \mathrm{O}_{3}$ and $\mathrm{Cr}_{2} \mathrm{O}_{3}$ /carbon samples are shown in Fig. 5. The first discharge curve of $\mathrm{Cr}_{2} \mathrm{O}_{3}$ /carbon shows a voltage slope from 1.3 to $0.22 \mathrm{~V}$ with ca. $230 \mathrm{mAh}$ $\mathrm{g}^{-1}$ capacity loss (Fig. 5a), corresponding to the decomposition of electrolyte and the formation of solid electrolyte interphase (SEI) films, which are common phenomena to the most anode materials [18, 33-37]. As the voltage decreases to $0.02 \mathrm{~V}$, the cell exhibits an initial specific capacity of $812.6 \mathrm{mAh} \mathrm{g}^{-1}$. A specific capacity of $449.1 \mathrm{mAh} \mathrm{g}^{-1}$ is obtained as the first charging is finished with the initial columbic efficiency (the ratio of charge capacity to discharge capacity) is $55 \%$. The capacity of $\mathrm{Cr}_{2} \mathrm{O}_{3} /$ carbon nanocomposites remains around $465.5 \mathrm{mAh} \mathrm{g}^{-1}$ after 150 cycles. In comparison, the first discharge curve of pure $\mathrm{Cr}_{2} \mathrm{O}_{3}$ (Fig. 5b) shows a voltage drop to 
$0.02 \mathrm{~V}$ and the initial specific capacity is $635.4 \mathrm{mAh} \mathrm{g}^{-1}$. The capacity of pure $\mathrm{Cr}_{2} \mathrm{O}_{3}$ rapidly decreases to $71.2 \mathrm{mAh} \mathrm{g}^{-1}$ after 150 cycles, arising from the volume change and aggregation of $\mathrm{Cr}_{2} \mathrm{O}_{3}$ during discharge/charge processes [38, 39]. A better capacity retention of the $\mathrm{Cr}_{2} \mathrm{O}_{3} /$ carbon nanocomposites can be assigned to the fact that the carbon sheets can accommodate the volume change and reduce the aggregation of $\mathrm{Cr}_{2} \mathrm{O}_{3}$ particles during discharge/charge processes, leading to a higher lithium activity. Meanwhile, the presence of carbon sheets can also improve the electrical conductivity.

Fig. 5c shows the $\mathrm{CV}$ curves for the $\mathrm{Cr}_{2} \mathrm{O}_{3} /$ carbon electrode in the initial three cycles. The cathodic peaks around $0.70 \mathrm{~V}$ are ascribed to the electrolyte decomposition and concomitant SEI formation [40], which are mainly observed during the first cycle and almost disappeared in the following cycles. The peak at $0.01 \mathrm{~V}$ corresponds to the reduction reaction of $\mathrm{Cr}_{2} \mathrm{O}_{3}$ with $\mathrm{Li}^{+}$ [41]. One broad oxidation peak observed between 0.54 and $1.76 \mathrm{~V}$ in the anodic scan is attributed to the oxidation of $\mathrm{Cr}^{0}$ to $\mathrm{Cr}^{3+}$ and the decomposition of $\mathrm{Li}_{2} \mathrm{O}$ [42]. In the $\mathrm{CV}$ curves of pure carbon electrode (Fig. 5d), two cathodic peaks at 0.01 and $1.21 \mathrm{~V}$ are observed corresponding to the $\mathrm{Li}^{+}$ions insertion into carbon [43]. The cathodic peak ascribed to the reduction of $\mathrm{Cr}^{3+}$ to $\mathrm{Cr}^{0}$ also appears at $0.01 \mathrm{~V}$ (Fig. 5c). After the second cycle, the CV curves tend to overlap, suggesting that the electrode exhibits the gradually enhanced cycling stability.

Fig. 5e shows the cycling performances of $\mathrm{Cr}_{2} \mathrm{O}_{3} /$ carbon nanocomposites evaluated at a constant current density of $100 \mathrm{~mA} \mathrm{~g}^{-1}$. It's found that the $\mathrm{Cr}_{2} \mathrm{O}_{3} /$ carbon nanocomposites deliver a stable reversible capacity of $465.5 \mathrm{mAh} \mathrm{g}^{-1}$ after 150 cycles. The coulombic efficiency of the $\mathrm{Cr}_{2} \mathrm{O}_{3} /$ carbon nanocomposites quickly reaches $98.6 \%$ in the second cycle, and even remains 
more than $97 \%$ from the third to the $150^{\text {th }}$ cycle. The capacity of the $\mathrm{Cr}_{2} \mathrm{O}_{3} /$ carbon nanocomposites in the first cycle is $812.6 \mathrm{mAh} \mathrm{g}^{-1}$, lower than the theoretical capacity of $\mathrm{Cr}_{2} \mathrm{O}_{3}$ (1058 $\mathrm{mAh} \mathrm{g}^{-1}$ ) due to the addition of carbon with low capacity ( $372 \mathrm{mAh} \mathrm{g}^{-1}$ for graphite). From the cycling test, pure carbon only delivers a stable reversible capacity of $235.4 \mathrm{mAh} \mathrm{g}^{-1}$ after 43 cycles (Fig. 5e). As a comparison, the cycling performance of $\mathrm{Cr}_{2} \mathrm{O}_{3}$ at a current density of 100 $\mathrm{mA} \mathrm{g}^{-1}$ is also shown in Fig. 5e. The capacity for $\mathrm{Cr}_{2} \mathrm{O}_{3}$ decreases successively with cycling (71.2 $\mathrm{mAh} \mathrm{g}^{-1}$ after 150 cycles). Thus, the $\mathrm{Cr}_{2} \mathrm{O}_{3} /$ carbon nanocomposites have a better cycling stability and higher specific capacity retention than $\mathrm{Cr}_{2} \mathrm{O}_{3}$. These results suggest that the carbon sheets in the nanocomposites are beneficial to the cycling stability. The as-prepared $\mathrm{Cr}_{2} \mathrm{O}_{3}$ /carbon nanocomposites show a better cycling stability (518.5 $\mathrm{mAh} \mathrm{g}^{-1}$ after 20 cycles) than C- $\mathrm{Cr}_{2} \mathrm{O}_{3}$ composites (460 mAh g ${ }^{-1}$ after 20 cycles) prepared by ball-milling commercial $\mathrm{Cr}_{2} \mathrm{O}_{3}$ with sugar and pyrolyzed in a tube-furnace at $600{ }^{\circ} \mathrm{C}$ for $12 \mathrm{hrs}$ under argon atmosphere [44], in which the capacities were decreased successively during 20 cycles.

The cells were cycled at various current densities for every ten cycles to investigate the rate performance of the $\mathrm{Cr}_{2} \mathrm{O}_{3}$ /carbon nanocomposites. As shown in Fig. 5f, the $\mathrm{Cr}_{2} \mathrm{O}_{3} /$ carbon nanocomposites deliver a reversible capacity of $580.6,448.7,287.2$, and $144.8 \mathrm{mAh} \mathrm{g}^{-1}$ at a current density of $100,200,400$, and $800 \mathrm{~mA} \mathrm{~g}^{-1}$, respectively. As the current density returns to $100 \mathrm{~mA} \mathrm{~g}^{-1}$ after the rate performance test, the discharge capacity is $479.2 \mathrm{mAh} \mathrm{g}^{-1}$. In contrast, the $\mathrm{Cr}_{2} \mathrm{O}_{3}$ anode only delivers a reversible capacity of $174.4,60.5,29.5$, and $13.6 \mathrm{mAh} \mathrm{g}^{-1}$ at a current density of $100,200,400$, and $800 \mathrm{~mA} \mathrm{~g}^{-1}$, respectively. Apparently, the $\mathrm{Cr}_{2} \mathrm{O}_{3} /$ carbon anode exhibits better rate capability than pure $\mathrm{Cr}_{2} \mathrm{O}_{3}$. It is believed that the carbon sheets in the 
$\mathrm{Cr}_{2} \mathrm{O}_{3}$ /carbon nanocomposites are favorable to increase the electrical conductivity between $\mathrm{Cr}_{2} \mathrm{O}_{3}$ nanoparticles as proved in EIS analysis and finally improve the cycling and rate performances.

Fig. 6 shows the Nyquist plots, which exhibit a depressed semicircle in the high and medium frequency and a sloped straight line in the low frequency. Generally, the diameter of the semicircle is related to the charge-transfer process occurring at the electrode/electrolyte interface, and is in direct proportion to the impedance including electrolyte resistance $\left(\mathrm{R}_{\mathrm{e}}\right)$, surface film resistance $\left(R_{\text {ff }}\right)$, and charge transfer resistance $\left(R_{c t}\right)[40,45,46]$. The inclined line in the low frequency range corresponds to the Warburg impedance associated with the lithium ion diffusion process inside the electrode, and the slope of the straight line is in inverse proportion to the Warburg impedance [29]. As shown in the inset of Fig. 6, the diameter of the semicircle for the $\mathrm{Cr}_{2} \mathrm{O}_{3}$ /carbon nanocomposites is smaller than that of pure $\mathrm{Cr}_{2} \mathrm{O}_{3}$, indicating that the carbon sheets improve the electrical conductivity and charge transfer at the interface of $\mathrm{Cr}_{2} \mathrm{O}_{3}$ nanoparticles. In addition, the $\mathrm{Cr}_{2} \mathrm{O}_{3}$ /carbon nanocomposites show larger slope than pure $\mathrm{Cr}_{2} \mathrm{O}_{3}$ in the low frequency region (Fig. 6), suggesting a better lithium ion diffusion ability of nanocomposites. It's concluded that the $\mathrm{Cr}_{2} \mathrm{O}_{3}$ /carbon nanocomposites exhibit lower impedances (including $\mathrm{R}_{\mathrm{e}}, \mathrm{R}_{\mathrm{sf}}, \mathrm{R}_{\mathrm{ct}}$ and Warburg impedance) at the electrode/electrolyte interface and inside the electrode. This illustrates that the prepared $\mathrm{Cr}_{2} \mathrm{O}_{3}$ /carbon nanocomposites have higher charge transfer and lithium ion diffusion rate than pure $\mathrm{Cr}_{2} \mathrm{O}_{3}$, which finally result in the enhanced capacity retention and rate performance $[29,47]$. The carbon sheets in the nanocomposites not only play as a buffer to cushion the volume change, but also prevent the aggregation of $\mathrm{Cr}_{2} \mathrm{O}_{3}$ during discharge/charge processes. This is beneficial to maintaining the structural integrity of 
electrode and prolonging the cycling life of LIBs.

To further investigate the effect of carbon sheets in the $\mathrm{Cr}_{2} \mathrm{O}_{3} /$ carbon nanocomposite electrode on the LIBs, the morphology of $\mathrm{Cr}_{2} \mathrm{O}_{3}$ and $\mathrm{Cr}_{2} \mathrm{O}_{3}$ /carbon nanocomposites is observed by SEM after 150 cycles at a current density of $100 \mathrm{~mA} \mathrm{~g}^{-1}$ and the results are shown in Fig. 7. In pure $\mathrm{Cr}_{2} \mathrm{O}_{3}$ electrode, it is clearly seen that the original $\mathrm{Cr}_{2} \mathrm{O}_{3}$ particles have been pulverized due to the large volume change and the particle size decreased from ca. 70 to $20 \mathrm{~nm}$ (Fig. 3a \& Fig. 7a). The pulverized particles were aggregated to form more compact structure. However, there are no obvious variations on the morphology and particle size of $\mathrm{Cr}_{2} \mathrm{O}_{3}$ for the $\mathrm{Cr}_{2} \mathrm{O}_{3} /$ carbon nanocomposite electrode before and after 150 cycles (Fig. 3b \& Fig. 7b), illustrating that the carbon sheets can alleviate the volume change and prevent the aggregation of $\mathrm{Cr}_{2} \mathrm{O}_{3}$ particles during the discharge/charge processes. After 150 cycles, the elemental mapping (Fig. 7c, d\&e) reveals the uniform distribution of $\mathrm{Cr}, \mathrm{O}$ and $\mathrm{C}$ elements, suggesting that the charge/discharge processes did little to break down the integrity of the electrode.

\section{Conclusion}

In this work, the nanocomposites with in-situ synthesized $\mathrm{Cr}_{2} \mathrm{O}_{3}$ nanoparticles embedded in carbon sheets were prepared by combining a sol-gel approach with an efficient carbonization process using glycine as carbon source. As anode materials for $\mathrm{LIBs}$, the $\mathrm{Cr}_{2} \mathrm{O}_{3} /$ carbon nanocomposites exhibit superior cycling performance and rate performances compared with pure $\mathrm{Cr}_{2} \mathrm{O}_{3}$ nanoparticles. The carbon sheets play an important role on improving the electrical 
conductivity of $\mathrm{Cr}_{2} \mathrm{O}_{3}$ as well as acting as a favorable buffer to the volume change during the lithiation/delithiation, leading to an enhanced electrochemical performance.

\section{Acknowledgements}

This work was supported by the Independent Innovation Foundations of Shandong University (2012ZD001, 2012JC013). The authors also acknowledge the financial supports from the Doctoral Program of Higher Education of China (20130131110068), New Century Excellent Talent Program (NCET-10-0545), State Education Ministry, and Natural Science Fund for Distinguished Young Scholars of Shandong (JQ201312). Z. Guo appreciates the supports from National Science Foundation (CMMI 10-30755 and CMMI 13-14486) USA.

\section{References:}

[1] H. Hu, L. Yu, X.H. Gao, Z. Lin, X.W. Lou, Hierarchical tubular structures constructed from ultrathin $\mathrm{TiO}_{2}(\mathrm{~B})$ nanosheets for highly reversible lithium storage, Energy \& Environmental Science 2015, DOI: 10.1039/C5EE00101C.

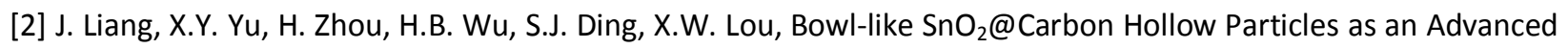
Anode Material for Lithium-Ion Batteries, Angewandte Chemie International Edition 53 (2014) 12803-12807.

[3] L. Zhang, H.B. Wu, B. Liu, X. W. Lou, Formation of porous $\mathrm{SnO}_{2}$ microboxes via selective leaching for highly reversible lithium storage, Energy \&Environmental Science 7 (2014) 1013-1017.

[4] V. Pralong, J.B. Leriche, B. Beaudoin, E. Naudin, M. Morcrette, J.M. Tarascon, Electrochemical study of nanometer $\mathrm{CO}_{3} \mathrm{O}_{4}, \mathrm{Co}, \mathrm{CoSb}_{3}$ and $\mathrm{Sb}$ thin films toward lithium, Solid State Ionics 166 (2004) 295-305.

[5] K.T. Nam, D.-W. Kim, P.J. Yoo, C.-Y. Chiang, N. Meethong, P.T. Hammond, Y.-M. Chiang, A.M. Belcher, Virus-enabled synthesis and assembly of nanowires for lithium ion battery electrodes, science 312 (2006) $885-888$.

[6] X.H. Ma, Q.Y. Wan, X. Huang, C.X. Ding, Y. Jin, Y.B. Guan, C.H. Chen, Synthesis of three-dimensionally porous $\mathrm{MnO}$ thin films for lithium-ion batteries by improved Electrostatic Spray Deposition technique, Electrochimica Acta 121 (2014) 15-20.

[7] P.L. Taberna, S. Mitra, P. Poizot, P. Simon, J.M. Tarascon, High rate capabilities $\mathrm{Fe}_{3} \mathrm{O}_{4}$-based $\mathrm{Cu}$ nano-architectured electrodes for lithium-ion battery applications, Nature materials 5 (2006) 567-573.

[8] X. Gao, J. Bao, G. Pan, H. Zhu, P. Huang, F. Wu, D. Song, Preparation and electrochemical performance of polycrystalline and single crystalline $\mathrm{CuO}$ nanorods as anode materials for Li ion battery, The Journal of Physical Chemistry B 108 (2004) 5547-5551.

[9] T. Nakajima, V. Gupta, Y. Ohzawa, H. Iwata, A. Tressaud, E. Durand, Electrochemical properties and structures 
of surface-fluorinated graphite for the lithium ion secondary battery, Journal of fluorine chemistry 114 (2002) 209-214.

[10] H. Li, P. Balaya, J. Maier, Li-storage via heterogeneous reaction in selected binary metal fluorides and oxides, Journal of the Electrochemical Society 151 (2004) A1878-A1885.

[11] G. Derrien, J. Hassoun, S. Panero, B. Scrosati, Nanostructured Sn-C composite as an advanced anode material in high-performance Lithium-ion batteries, Advanced Materials 19 (2007) 2336-2340.

[12] K. Zhong, X. Xia, B. Zhang, H. Li, Z. Wang, L. Chen, MnO powder as anode active materials for lithium ion batteries, Journal of Power Sources 195 (2010) 3300-3308.

[13] L. Dupont, S. Laruelle, S. Grugeon, C. Dickinson, W. Zhou, J.M. Tarascon, Mesoporous $\mathrm{Cr}_{2} \mathrm{O}_{3}$ as negative electrode in lithium batteries: TEM study of the texture effect on the polymeric layer formation, Journal of Power Sources 175 (2008) 502-509.

[14] W. Yue, S. Tao, J. Fu, Z. Gao, Y. Ren, Carbon-coated graphene- $\mathrm{Cr}_{2} \mathrm{O}_{3}$ composites with enhanced electrochemical performances for Li-ion batteries, Carbon 65 (2013) 97-104.

[15] G.X. Zhao, T. Wen, J. Zhang, J.X. Li, H.L. Dong, X.K. Wang, Y.G. Guo,W.P. Hu, Two-dimensional $\mathrm{Cr}_{2} \mathrm{O}_{3}$ and interconnected graphene- $\mathrm{Cr}_{2} \mathrm{O}_{3}$ nanosheets: synthesis and their application in lithium storage, Journal of Materials Chemistry A 2 (2014) 944-948.

[16] Q. Wang, X.K. Wang, Z.F. Chai,W.P. Hu, Low-temperature plasma synthesis of carbon nanotubes and graphene based materials and their fuel cell applications, Chemical Society Review, 42 (2013) 8821-8834.

[17] H. Chen, J.X. Li, X.L. Wu, X.K. Wang, Synthesis of Alumina-Modified Cigarette Soot Carbon As an Adsorbent for Efficient Arsenate Removal, Industrial \& Engineering Chemistry Research, 53 (2014) 16051-16060.

[18] L.Y. Jiang, S. Xin, X.L. Wu, H. Li, Y.G. Guo, L.J. Wan, Non-sacrificial template synthesis of $\mathrm{Cr}_{2} \mathrm{O}_{3}$-C hierarchical core/shell nanospheres and their application as anode materials in lithium-ion batteries, Journal of Materials Chemistry 20 (2010) 7565-7569.

[19] H. Gu, Y. Huang, X. Zhang, Q. Wang, J. Zhu, L. Shao, N. Haldolaarachchige, D.P. Young, S. Wei, Z. Guo, Magnetoresistive polyaniline-magnetite nanocomposites with negative dielectrical properties, Polymer 53 (2012) 801-809.

[20] H. Gu, J. Guo, H. Wei, X. Zhang, J. Zhu, L. Shao, Y. Huang, N. Haldolaarachchige, D.P. Young, S. Wei, Magnetoresistive conductive polymer-tungsten trioxide nanocomposites with ultrahigh sensitivity at low magnetic field, Polymer 55 (2014) 944-950.

[21] L. Li, Z. Zhu, X. Yao, G. Lu, Z. Yan, Synthesis and characterization of chromium oxide nanocrystals via solid thermal decomposition at low temperature, Microporous and Mesoporous Materials 112 (2008) 621-626.

[22] S. Kazarian, K. Chan, Applications of ATR-FTIR spectroscopic imaging to biomedical samples, Biochimica et Biophysica Acta (BBA)-Biomembranes 1758 (2006) 858-867.

[23] S. Wibowo, G. Velazquez, V. Savant, J.A. Torres, Effect of chitosan type on protein and water recovery efficiency from surimi wash water treated with chitosan-alginate complexes, Bioresource technology 98 (2007) 539-545.

[24] S. Yang, W. Yue, J. Zhu, Y. Ren, X. Yang, Graphene-Based Mesoporous $\mathrm{SnO}_{2}$ with Enhanced Electrochemical Performance for Lithium-Ion Batteries, Advanced Functional Materials 23 (2013) 3570-3576.

[25] P. Gibot, L. Vidal, Original synthesis of chromium (III) oxide nanoparticles, Journal of the European Ceramic Society 30 (2010) 911-915.

[26] J. Robertson, Diamond-like amorphous carbon, Materials Science and Engineering R 37 (2002) 129-281. 
[27] S. Li, L. Xu, G. Li, et al., In-situ controllable synthesis and performance investigation of carbon-coated monoclinic and hexagonal $\mathrm{LiMnBO}_{3}$ composites as cathode materials in lithium-ion batteries, Journal of Power Sources 236 (2013) 54-60.

[28] H. Gu, S.B. Rapole, J. Sharma, Y. Huang, D. Cao, H.A. Colorado, Z. Luo, N. Haldolaarachchige, D.P. Young, B. Walters, Magnetic polyaniline nanocomposites toward toxic hexavalent chromium removal, RSC Advances 2 (2012) 11007-11018.

[29] G. Lu, S. Qiu, J. Liu, X. Wang, C. He, Y.-J. Bai, Enhanced Electrochemical Performance of Zn-Doped $\mathrm{Fe}_{3} \mathrm{O}_{4}$ with Carbon Coating, Electrochimica Acta 117 (2014) 230-238.

[30] H. Gu, S.B. Rapole, Y. Huang, D. Cao, Z. Luo, S. Wei, Z. Guo, Synergistic interactions between multi-walled carbon nanotubes and toxic hexavalent chromium, Journal of Materials Chemistry A 1 (2013) 2011-2021.

[31] H. Gu, J. Guo, Q. He, Y. Jiang, Y. Huang, N. Haldolaarachige, Z. Luo, D.P. Young, S. Wei, Z. Guo, Magnetoresistive polyaniline/multi-walled carbon nanotube nanocomposites with negative permittivity, Nanoscale 6 (2014) 181-189.

[32] A. M. Tshavhungwe, M. Layh and N. J. Coville, Cobalt Ion Incorporation into Periodic Mesoporous Organosilica Materials Synthesized by Co-condensation of 1,2-Bistrimethoxysilylethane with 3-Glycidoxypropyltriethoxysilane, Journal of Sol-Gel Science and Technology, 29 (2004) 167-177.

[33] J. Chen, L.N. Xu, W.Y. Li, X.L. Gou, $\alpha-\mathrm{Fe} 2 \mathrm{O} 3$ nanotubes in gas sensor and lithium-ion battery applications, Advanced Materials 17 (2005) 582-586.

[34] C. Wu, P. Yin, X. Zhu, C. OuYang, Y. Xie, Synthesis of hematite $\left(\alpha-\mathrm{Fe}_{2} \mathrm{O}_{3}\right)$ nanorods: diameter-size and shape effects on their applications in magnetism, lithium ion battery, and gas sensors, The Journal of Physical Chemistry $B$ 110 (2006) 17806-17812.

[35] J. Liu, Y. Li, H. Fan, Z. Zhu, J. Jiang, R. Ding, Y. Hu, X. Huang, Iron oxide-based nanotube arrays derived from sacrificial template-accelerated hydrolysis: large-area design and reversible lithium storage, Chemistry of Materials 22 (2009) 212-217.

[36] H.S. Kim, Y. Piao, S.H. Kang, T. Hyeon, Y.-E. Sung, Uniform hematite nanocapsules based on an anode material for lithium ion batteries, Electrochemistry Communications 12 (2010) 382-385.

[37] J. Ma, J. Lian, X. Duan, X. Liu, W. Zheng, $\alpha-\mathrm{Fe}_{2} \mathrm{O}_{3}$ : hydrothermal synthesis, magnetic and electrochemical properties, The Journal of Physical Chemistry C 114 (2010) 10671-10676.

[38] Z.M. Cui, L.Y. Jiang, W.G. Song, Y.G. Guo, High-yield gas- liquid interfacial synthesis of highly dispersed $\mathrm{Fe}_{3} \mathrm{O}_{4}$ nanocrystals and their application in lithium-ion batteries, Chemistry of Materials 21 (2009) 1162-1166.

[39] J.S. Xu, Y.J. Zhu, Monodisperse $\mathrm{Fe}_{3} \mathrm{O}_{4}$ and $\mathrm{\gamma}-\mathrm{Fe}_{2} \mathrm{O}_{3}$ magnetic mesoporous microspheres as anode materials for lithium-ion batteries, ACS applied materials \& interfaces 4 (2012) 4752-4757.

[40] B. Guo, M. Chi, X. G. Sun, S. Dai, Mesoporous carbon- $-\mathrm{Cr}_{2} \mathrm{O}_{3}$ composite as an anode material for lithium ion batteries, Journal of Power Sources 205 (2012) 495-499.

[41] Z. Cao, M. Qin, B. Jia, L. Zhang, Q. Wan, M. Wang, A.A. Volinsky, X. Qu, Facile route for synthesis of mesoporous $\mathrm{Cr}_{2} \mathrm{O}_{3}$ sheet as anode materials for Li-ion batteries, Electrochimica Acta 139 (2014) 76-81.

[42] B. Sun, Z. Chen, H.-S. Kim, H. Ahn, G. Wang, MnO/C core-shell nanorods as high capacity anode materials for lithium-ion batteries, Journal of Power Sources 196 (2011) 3346-3349.

[43] S. Yuvaraj, K. Karthikeyan, L. Vasylechko, R.K. Selvan, Hydrothermal synthesis and characterization of $\mathrm{Co}_{2.85} \mathrm{Si}_{0.15} \mathrm{O}_{4}$ solid solutions and its carbon composite as negative electrodes for Li-ion batteries, Electrochimica Acta, 158 (2015) 446-456. 
[44] J. Hu, H. Li, X. Huang, L. Chen, Improve the electrochemical performances of $\mathrm{Cr}_{2} \mathrm{O}_{3}$ anode for lithium ion batteries, Solid State lonics 177 (2006) 2791-2799.

[45] H. Gu, H. Wei, J. Guo, N. Haldolaarachige, D.P. Young, S. Wei, Z. Guo, Hexavalent chromium synthesized polyaniline nanostructures: Magnetoresistance and electrochemical energy storage behaviors, Polymer 54 (2013) 5974-5985.

[46] Y. Huang, Z. Dong, D. Jia, Z. Guo, W.L. Cho, Preparation and characterization of core-shell structure $\mathrm{Fe}_{3} \mathrm{O}_{4} / \mathrm{C}$ nanoparticles with unique stability and high electrochemical performance for lithium-ion battery anode material, Electrochimica Acta 56 (2011) 9233-9239.

[47] A.K. Rai, L.T. Anh, J. Gim, V. Mathew, J. Kang, B.J. Paul, J. Song, J. Kim, Simple synthesis and particle size effects of $\mathrm{TiO}_{2}$ nanoparticle anodes for rechargeable lithium ion batteries, Electrochimica Acta 90 (2013) 112-118. 


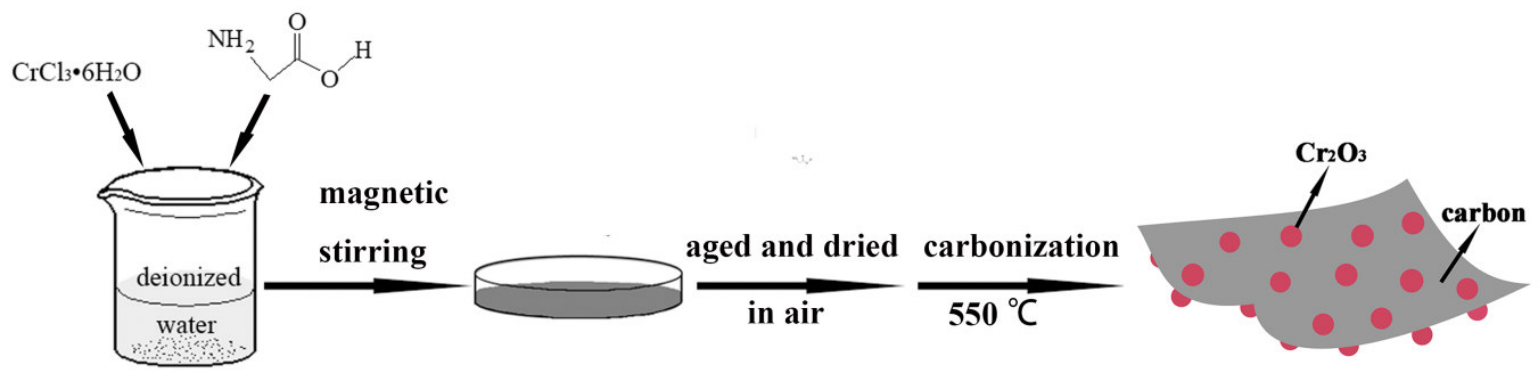

Scheme 1. Schematic preparation procedure of $\mathrm{Cr}_{2} \mathrm{O}_{3}$ /carbon nanocomposites. 


\section{Figures and Figure Captions:}
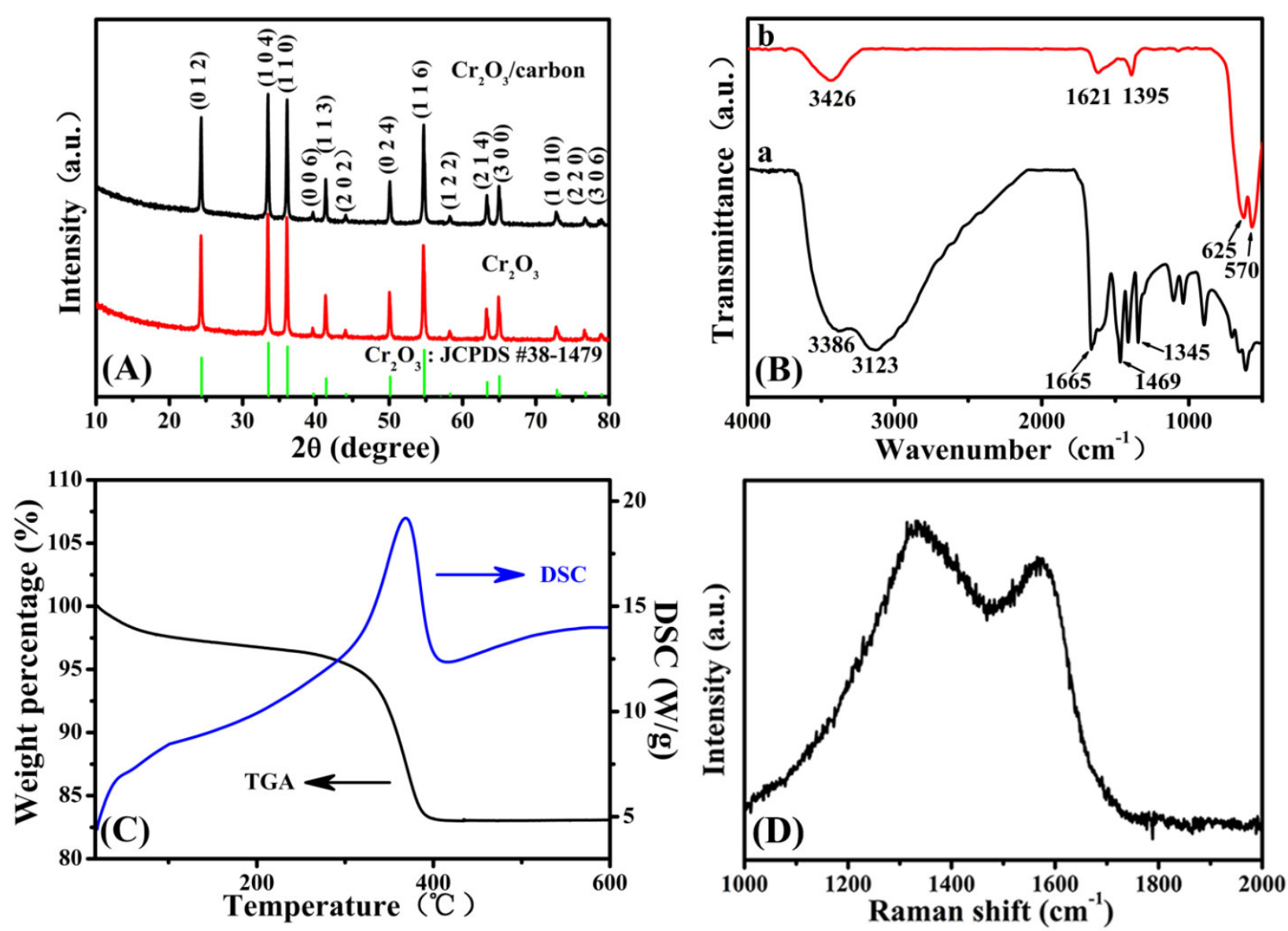

Fig. 1 (A) XRD patterns of $\mathrm{Cr}_{2} \mathrm{O}_{3} /$ carbon nanocomposites and pure $\mathrm{Cr}_{2} \mathrm{O}_{3}$; (B) FT-IR spectra of (a) gel precursor consisted $\mathrm{CrCl}_{3}$ with glycine and (b) $\mathrm{Cr}_{2} \mathrm{O}_{3} /$ carbon nanocomposites; (C) TGA/DSC curves of $\mathrm{Cr}_{2} \mathrm{O}_{3} /$ carbon nanocomposites at a heating rate of $10{ }^{\circ} \mathrm{C} \min ^{-1}$ under air condition; (D) Raman spectra of $\mathrm{Cr}_{2} \mathrm{O}_{3} /$ carbon nanocomposites. 

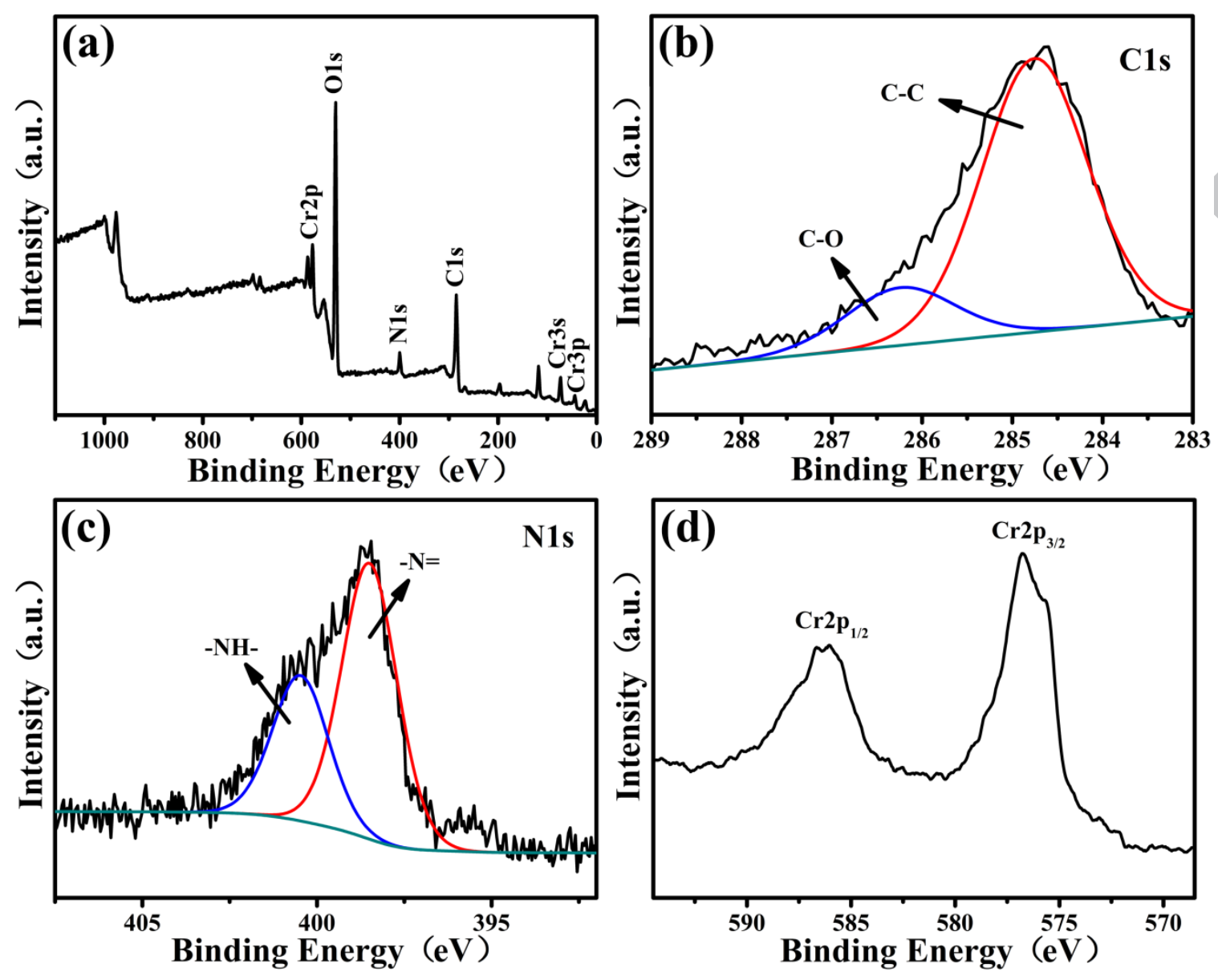

Fig. 2 XPS spectra of $\mathrm{Cr}_{2} \mathrm{O}_{3}$ /carbon nanocomposites: Survey scan (a) and high resolution spectra of (b) C1s, (c) N1s, and (d) Cr2p. 

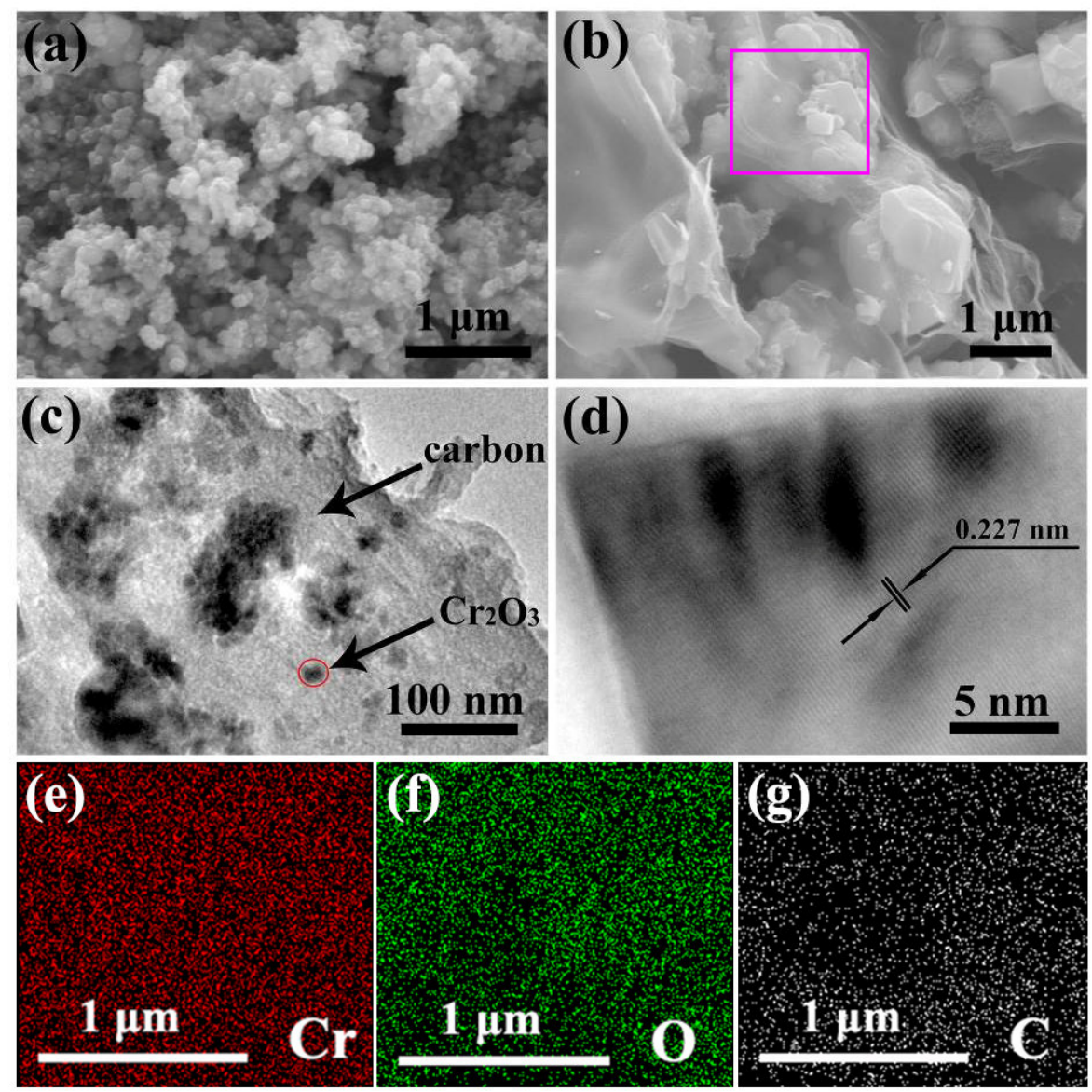

Fig. 3 SEM images of (a) $\mathrm{Cr}_{2} \mathrm{O}_{3}$ and (b) $\mathrm{Cr}_{2} \mathrm{O}_{3}$ /carbon nanocomposites; (c) TEM (d) HRTEM images of $\mathrm{Cr}_{2} \mathrm{O}_{3}$ /carbon nanocomposites and (e, f, g) EDX mapping image $(\mathrm{Cr}, \mathrm{O}, \mathrm{C})$ of $\mathrm{Cr}_{2} \mathrm{O}_{3} /$ carbon nanocomposites. 


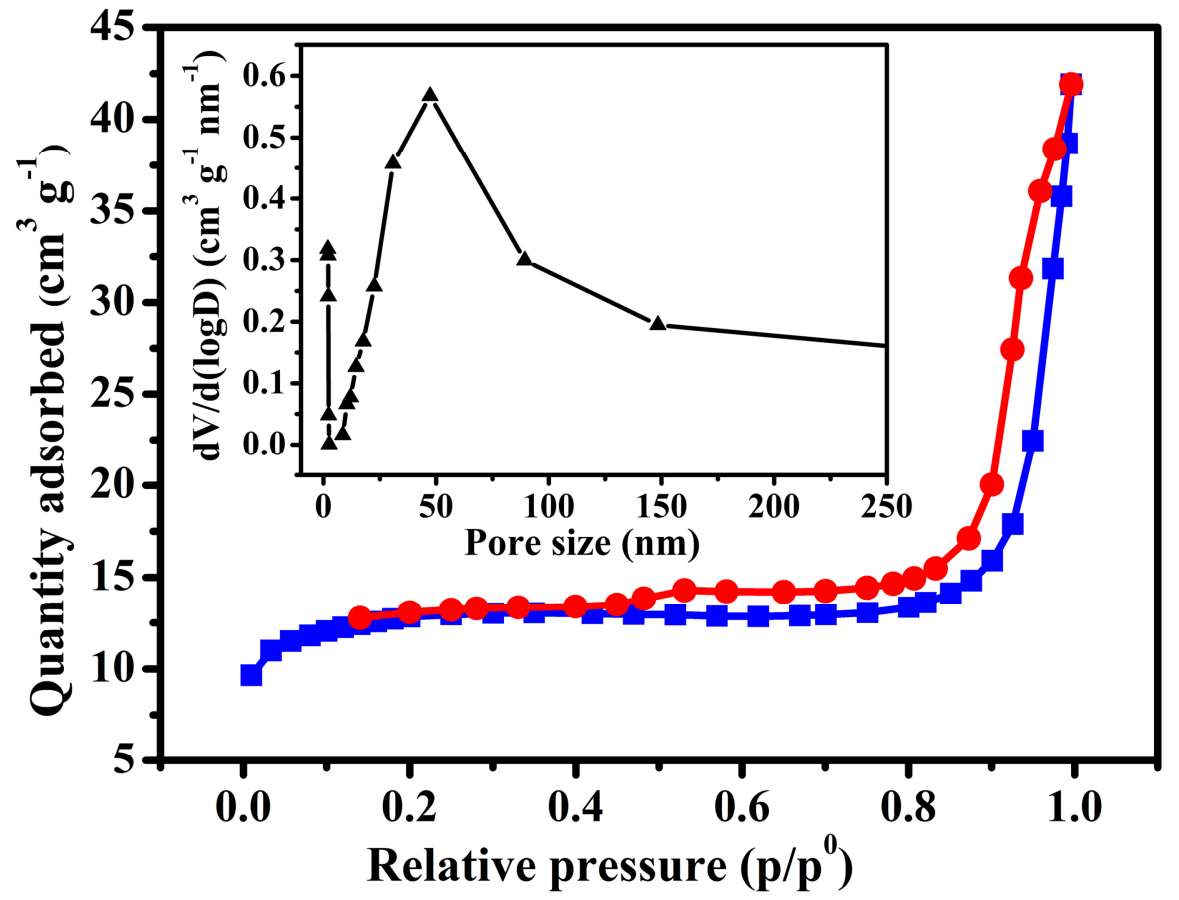

Fig..4 The nitrogen adsorption-desorption isotherms of $\mathrm{Cr}_{2} \mathrm{O}_{3} /$ carbon nanocomposites. Inset is the pore size distribution. 

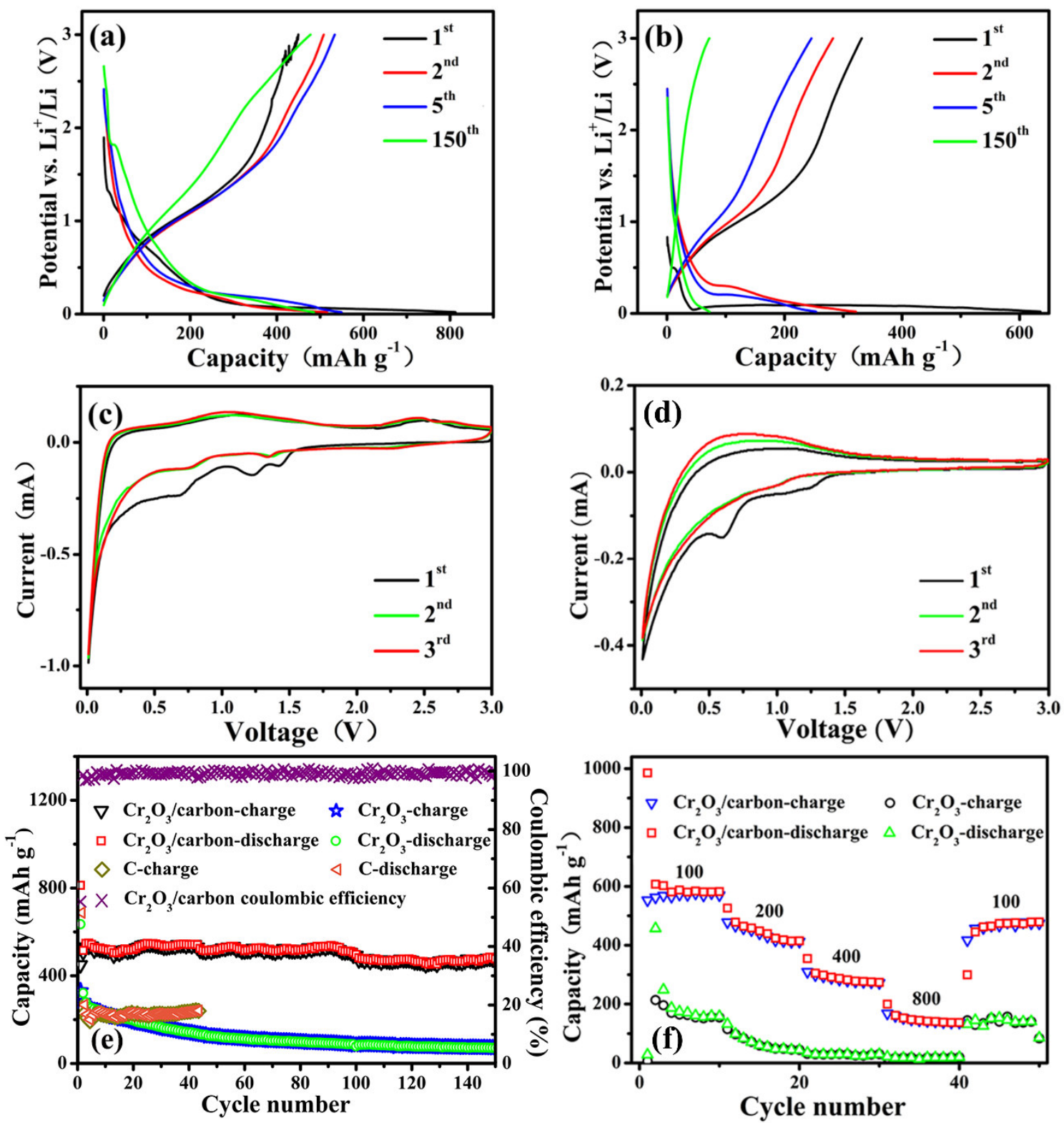

Fig. 5 Galvanostatic discharge/charge curves of the 1st, 2nd, 5th, and 150th cycles for (a) $\mathrm{Cr}_{2} \mathrm{O}_{3}$ /carbon nanocomposites and (b) $\mathrm{Cr}_{2} \mathrm{O}_{3}$; $\mathrm{CV}$ curves of (c) $\mathrm{Cr}_{2} \mathrm{O}_{3}$ /carbon nanocomposites and (d) $\mathrm{C}$; (e) Cycling performance of $\mathrm{Cr}_{2} \mathrm{O}_{3}$ /carbon nanocomposites and $\mathrm{Cr}_{2} \mathrm{O}_{3}$ at the current density of $100 \mathrm{~mA} \mathrm{~g}^{-1}$; and (f) rate capabilities. 


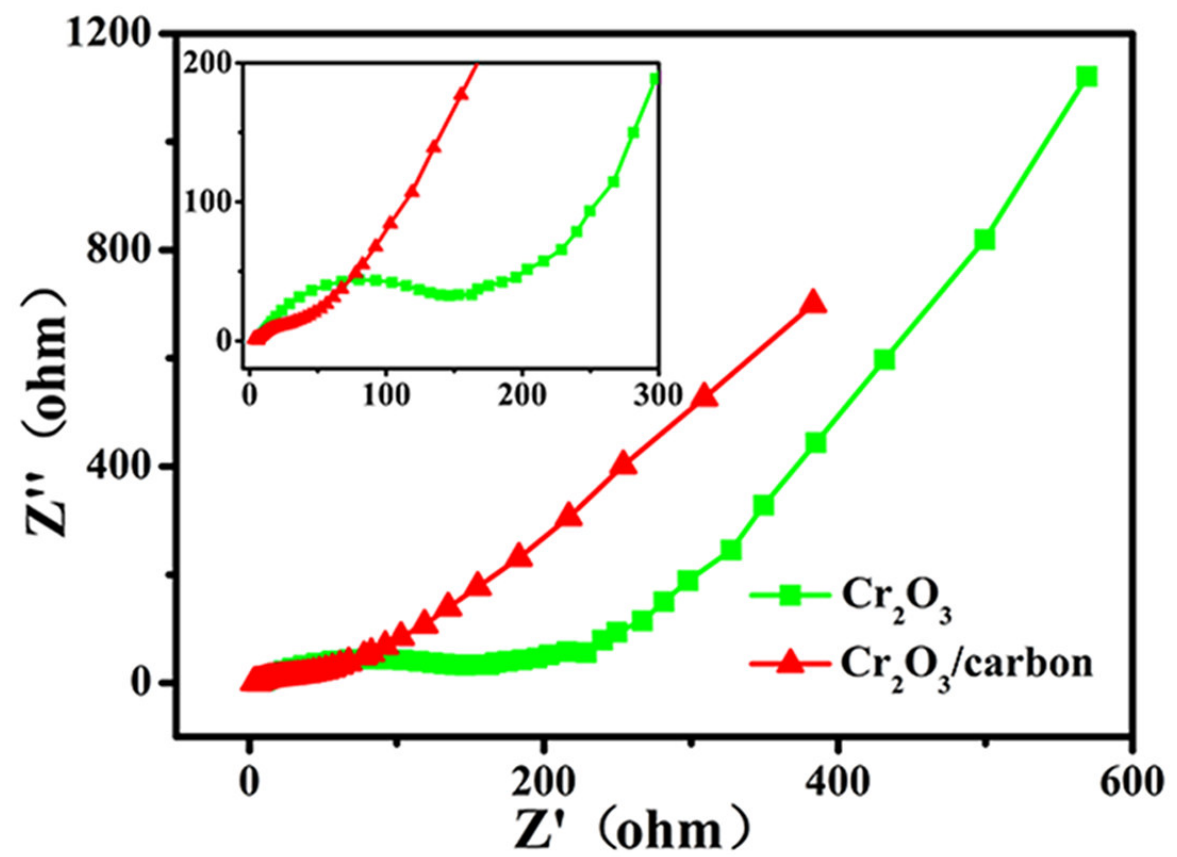

Fig. 6 Nyquist plots of $\mathrm{Cr}_{2} \mathrm{O}_{3}$ /carbon nanocomposites and $\mathrm{Cr}_{2} \mathrm{O}_{3}$. Inset is the impedance spectrum in the high and medium frequency. 


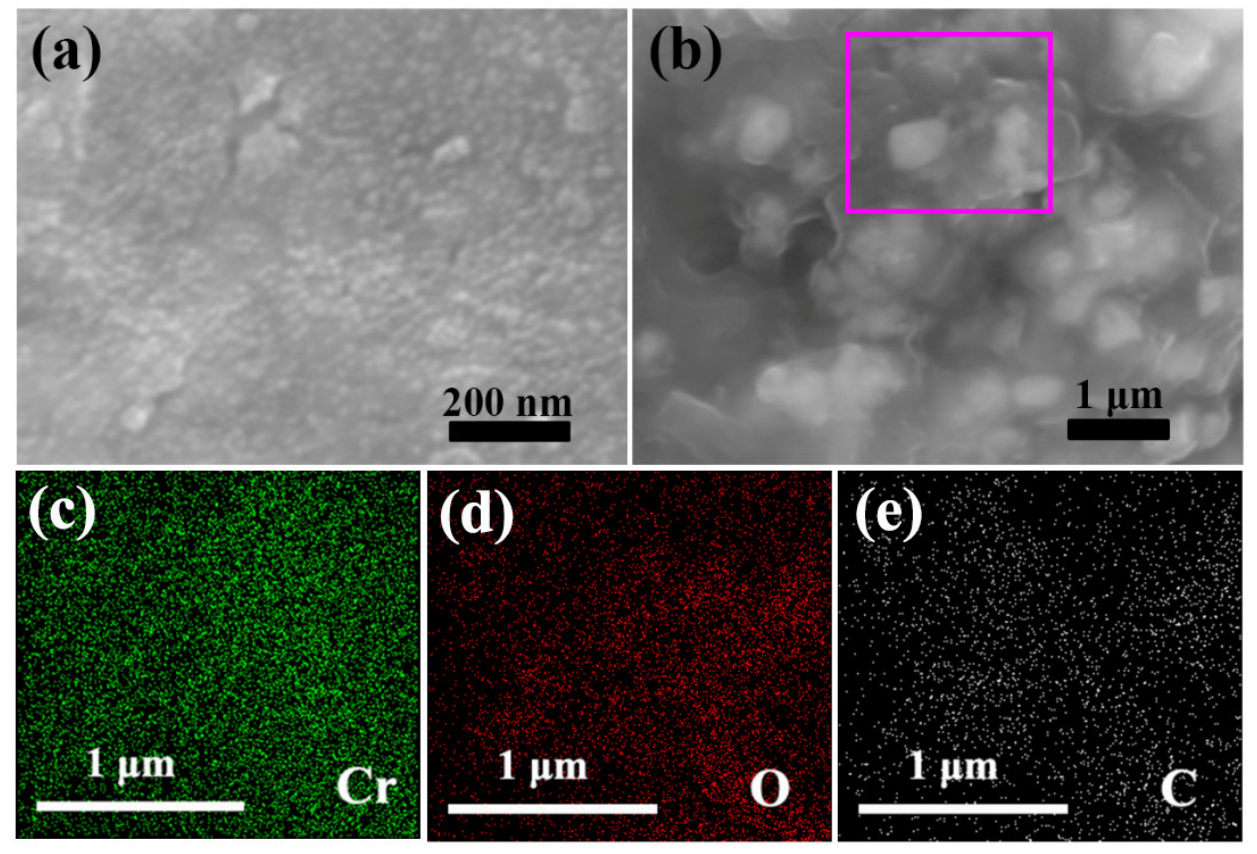

Fig. $7 \mathrm{SEM}$ images of (a) $\mathrm{Cr}_{2} \mathrm{O}_{3}$, (b) $\mathrm{Cr}_{2} \mathrm{O}_{3}$ /carbon nanocomposites after 150 cycles at the current density of $100 \mathrm{~mA} \mathrm{~g}^{-1}$ and (c, d, e) EDX mapping image (Cr, O, C) of $\mathrm{Cr}_{2} \mathrm{O}_{3} /$ carbon nanocomposites. 


\section{Graphical Abstract}
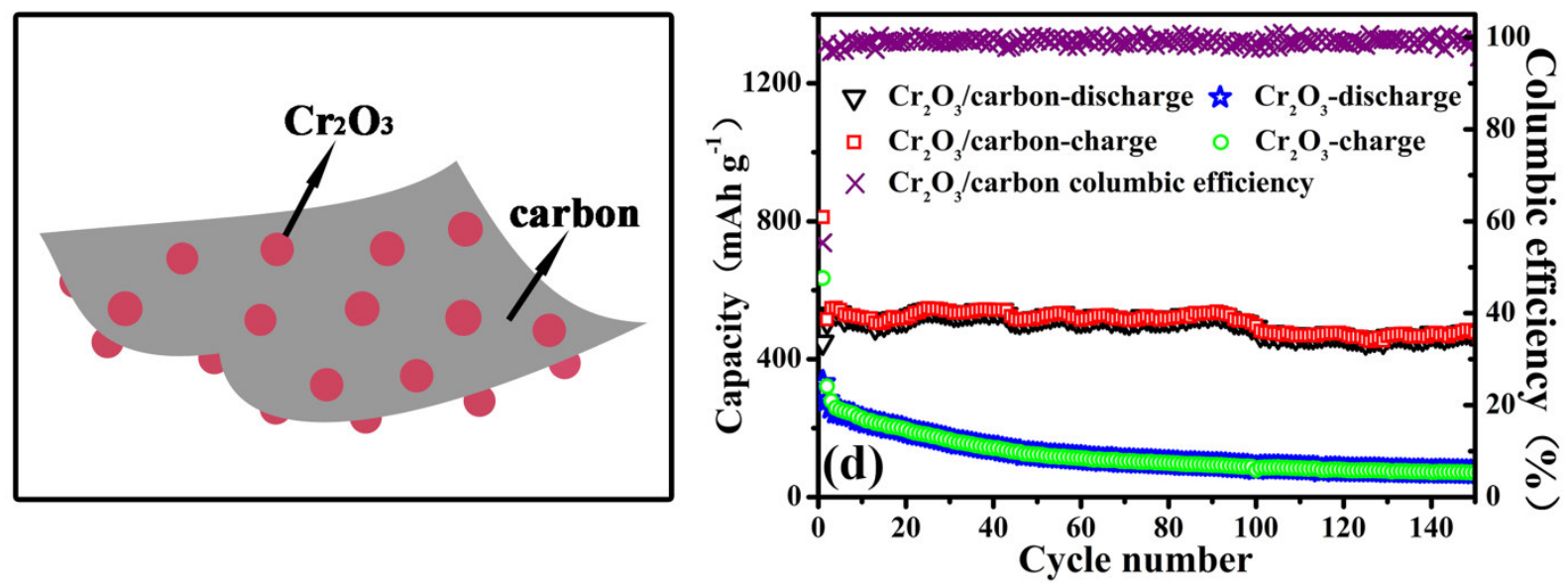

The $\mathrm{Cr}_{2} \mathrm{O}_{3}$ /carbon nanocomposites synthesized by directly carbonizing glycine- $\mathrm{CrCl}_{3}$ gel precursor exhibit superior cycling and rate performances as lithium-ion battery anode materials. 